\title{
Políticas de golpe - sobre o poder de voz e o poder de silenciamento
}

\section{Coup Politics - on voice power and power of silencing}

\author{
Janyne Sattler \\ Docente do departamento de filosofia da UFSC
}

Resumo: A proposta deste artigo é refletir sobre os significados engendrados pela voz masculina como a voz do poder por excelência, sinônima de voz pública e de legitimidade política cuja outorga é atribuída em detrimento das vozes femininas ou femininizadas, relegadas ao silêncio da domesticidade. Tais significados são construídos a partir da distinção público-privado-doméstico, oriunda das teorias políticas contratualistas modernas e da imposição social e econômica do capitalismo compreendido como fenômeno de contrarrevolução às lutas sociais anti-feudais. Tais significados reproduzem, sob a luz de uma conceituação aparentemente emancipatória, as imagens de exclusão e silenciamento presentes nos castigos mitológicos impostos sobre mulheres como Io, Eco e Filomela, e que repercutem nas políticas misóginas de texto e de linguagem vivenciadas contemporaneamente por mulheres na política.

Palavras-chave: poder; política; distinção público/privado; feminismo.

Abstract: The purpose of this paper is to reflect about the meanings brought about by the male voice as the voice of power par excellence, which is synonymous with public voice and has political legitimacy, contrary to feminine or femininized voices, which are relegated to the silence of domesticity. The construction of these meanings derive 
from the public-private-domestic distinction, stemming from modern contractualist political theories and the social and economic imposition of capitalism understood as a phenomenon of counterrevolution to anti-feudal social struggles. These meanings reproduce, in the light of a seemingly emancipatory conceptualization, the images of exclusion and silencing which are also present in the mythological punishments imposed over women such as Io, Eco and Filomela. They do have repercussions also on the misogynistic politics of text and language experienced by women in politics today.

Key-words: power; politics; public/private ditinction, feminism.

\section{Presidenta}

ensejo para este ensaio tem sua origem num outro tipo de empreitada, cuja realização se deu no quadro de uma conjuntura específica de reação nacional à censura, por parte do Ministério da Educação e da Cultura do Brasil, à disciplina sobre o golpe parlamentar de 2016, do professor de Ciência Política da Universidade de Brasília, Luis Felipe Miguel. Em 11 de abril de 2018, na mesa "O Gênero do Golpe", no contexto do "Ciclo de Debates: O Golpe de 2016 e o Futuro da Democracia no Brasil", na Universidade Federal de Santa Catarina, procedi à leitura do texto Presidenta - um texto literário, ou um texto manifesto, ou um texto político de desabafo, como se queira chamá-lo. Ele está disponível em um blog pessoal e numa coletânea mencionada nas referências, figurando, portanto, como texto independente. Os mesmos motivos daquela leitura, no entanto, atravessam o presente escrito, como tantos outros empreendimentos reflexivos que tenho desenvolvido desde então com urgência política manifesta e crescente em vista das políticas de golpe que não cessam de se acumular sobre nossos corpos destituídos de legitimidade cidadã desde que Dilma Rousseff foi impedida de terminar o seu mandato democraticamente oficializado.

Aquela leitura foi sem dúvida inesperada de uma acadêmica em filosofia. Mas ela recolocou em ato algumas tentativas que tenho levado a cabo para fazer corroborar parte de minha 
tese a respeito das margens textuais entre filosofia e literatura em prol de um certo tipo de engajamento que, se é emocionalmente reativo, é ao mesmo tempo também moral e político, e quebra - ou assim eu espero - com algumas normas típicas da filosofia acadêmica contemporânea em seu insulamento e incompetência comunicativa. Trata-se, neste sentido, de um imprescindível questionamento meta-filosófico - que é também político, mas sobre o qual não me deterei neste momento.

Ademais, aquela foi sem dúvida uma leitura política em variados de seus aspectos, corroborando uma outra parte de minha tese, desde uma perspectiva feminista, a respeito da política que instaura um poder no texto, na escrita e na linguagem. Porque, ao fim e ao cabo, é este o poder, de fato. Uma política, portanto, do texto, da escrita e da linguagem. Cujas possibilidades comportam engajamentos subversivos e insurreições democráticas. E é sobre esta tese que proponho a reflexão que se segue, versando, por um lado, sobre a relação das mulheres com o assim chamado mundo público da política e, por outro, sobre as reiteradas tentativas de domesticação de suas palavras, de seus corpos e de seu imaginário a partir de políticas sexuais de silenciamento (e de extermínio, em última instância, cujo corolário é a persistência da colonialidade) que se estendem a todos os corpos incompatíveis com as definições da masculinidade branca heterossexual de matriz eurocêntrica.

Trata-se, aqui, de uma incursão conceitual e da tentativa de compreensão de um quadro diagnóstico que se completa com a tarefa concomitante de reversão das políticas sexuais excludentes pela construção de políticas feministas inclusivas, como aquelas que privilegiam o texto, a palavra e a linguagem filosófica e literária (e política) não-canônica - como também tenho tentado fazer em outros lugares (Sattler, 2018 e 2020).

\section{Políticas de Golpe}

Em Mulheres e poder: um manifesto, Mary Beard nos oferece a triste história do silenciamento das mulheres ao longo da literatura e da cultura ocidental que desde a Odisseia, e depois com as Metamorfoses, relaciona inextricavelmente poder e dis- 
curso - ou, mais especificamente, poder masculino e discurso público. Os modos de silenciamento são mais ou menos materiais e corpóreos e as drásticas soluções de emudecimento são sintomáticas relativamente àquilo que de fato está em jogo quando se trata da manutenção dos privilégios outorgados pela simples investidura da masculinidade: Io transformada por Zeus (ou por Hera) numa vaca, Eco incapaz para sempre de se comunicar senão ouvindo apenas em sua própria voz a voz de todos os outros, e Filomela cujo estupro não pode ser denunciado porque também sua língua está cortada. Note-se que os mitos fundantes de Ovídio fundam reiteradamente a cultura do calar e a cultura do estupro, ainda que muitas das desqualificações do discurso feminino sejam "apenas" sugestões imagéticas, mas nem por isso menos responsáveis pelos números efetivamente contabilizados de violência contra as mulheres e outros seres femininizados.

Tendo já diante de si uma longa história literária, filosófica e cultural de descrédito e difamação das mulheres, Christine de Pizan interroga Dama Razão na Cidade das Damas - manifesto utópico de 1405 que compreendo como partícipe do que chamei acima de política do texto, da escrita e da linguagem - sobre os motivos de sermos tão desprezadas e de antemão condenadas: "Dizei-me, vos peço, por que tantos autores as maldizem em suas obras? O que os motiva? Pois, vós já me fizestes entender que eles estão errados. Será que é a Natureza que os leva a isso ou será que o fazem por ódio? Como isso acontece?" (Pizan, 2006, p.131 - uso aqui a tradução desenvolvida por Calado em sua tese de doutorado na UPFE). O termo 'misoginia' não fazia parte do vocabulário da filósofa medieval tal como faz parte hoje do nosso, mas assim como Mary Beard, Pizan está interessada em compreender e em denunciar os complexos e complicados enredamentos entre poder e discurso, e entre poder e retórica, que se estendem para além do "simples diagnóstico de 'misoginia"' (Beard, 2018, p. 20). Neste sentido, a pergunta é "por que de fato nos odeiam" como desdobramento de uma pergunta ainda mais intricada e emaranhada colocada por Pizan: "o que os motiva?" 
O poder, ou o privilégio, ou os privilégios do poder, poderiam constituir respostas abreviadas a "uma longa história por trás de tudo" (Beard, 2018, p.20). Mas há qualificações e hipóteses bastante plausíveis para os significados deste poder e deste privilégio aparentes tão cedo quanto nas exemplificações das Metamorfoses citadas acima, e que eu gostaria de investigar também nos reflexos de suas imagens contemporâneas. - O pano de fundo, desde uma perspectiva da filosofia política feminista hodierna, é a estrutura das distinções entre público, privado e doméstico, que eu espero tornar explícita mais adiante.

Em um certo sentido, uma mulher que fala nunca pode ser de fato uma mulher - ainda quando o significado de 'mulher' já tenha sido questionado contra sua essencialização (risco sempre presente e no qual eu desejo não incorrer) e atravessado por outros tantos marcadores sociais. A animalização das mulheres em seu amplo espectro de possibilidades é uma das maneiras pelas quais procede a desqualificação do conteúdo de sua fala $e$ de sua voz, porque não se trata apenas do esvaziamento dos significantes, mas da própria materialidade sonora. Evidentemente, o processo é aqui devedor dos fundamentos filosóficos epistemológicos que separam em dicotomias hierarquizadas os valores cognitivos - que tornam-se também morais e políticos na suposta justificação racional de sua superioridade - da racionalidade e da animalidade, casados de maneira extremamente redutora, com os atributos do masculino e do feminino, respectivamente. Não à toa, os princípios dicotômicos sobre os quais se assenta nossa cultura ocidental e os lastros da colonização, cortam fundo na carne da terra, da natureza, dos animais não humanos, dos corpos de cores inadmitidas e das mulheres, sob o domínio hegemônico de uma única ideia: livre acesso à corporeidade. Note-se que todas as noções abstratas ligadas à masculinidade e ao próprio sujeito da racionalidade visam precisamente desencarnar e fazer passar despercebido o lugar do poder. Num dos vários truques permitidos por esta conceituação, a intangibilidade masculina é exatamente o que possibilita e concede a livre apropriação dos outros tornados meros corpos para usufruto dos corpos masculinos. 
Nem sempre a animalização das mulheres toma acepções tão literais quanto aquelas vislumbradas pela mitologia, mas a caracterização das vocalizações "femininas" - e vale aqui o "feminino" da homossexualidade também - é o quanto basta para o descrédito daquilo que é por elas expresso, já que a animalidade é o valor da irracionalidade e da incomunicabilidade. A literatura e a filosofia estão repletas de exemplos notáveis acerca da suposta incompreensibilidade da fala feminina em sua confluência com a voz animal, desde a chacota de Aristófanes às recomendações explícitas de Henry James e Jean-Jacques Rousseau, quanto ao "imenso poder para os grasnados" - "An immense power for quackery, my dear Miss Olive!" (James, 2009, p.156) - das manifestações públicas das mulheres e da impossibilidade de que a política se faça com tamanha bestialidade: "Até mesmo as vacas no campo, os cordeiros na charneca, os asnos na grama, mugem e balem e zurram com certa consistência e harmonia" (James, 2004, p.63, tradução minha). Evidentemente, a sonoridade do feminino não é desta forma ultrajante apenas porque supostamente desagradável aos ouvidos - muito embora, e de maneira inerentemente correlata, todo o edifício da estética da feminilidade se construa igualmente sobre os pressupostos de uma docilidade e passividade ao gosto da subjugação. Os motivos são da ordem da domesticação, da privatização ou da reprivatização dos corpos das mulheres, e apartamento de sua condição de cidadania. Contra o discurso público "esganiçado" das mulheres, portanto, a construção reiterada de uma ideologia de gênero - esta, sim, uma ideologia de gênero: "Para o bem de nossos lares, nossos filhos, nosso futuro e nossa honra nacional, que não tenhamos mulheres assim!" (idem, p.78). Rousseau, para além da ameaça de solteirice eterna às jovens letradas frente à sensatez masculina (Rousseau, 1979, p.355), - solteirice que constitui efetivamente uma ameaça quando o casamento é a única possibilidade de emprego para a menina branca da burguesia - é explícito quanto aos limites de seus domínios, cuja extrapolação, já no próprio "lar", resulta em desastre:

Há grande diferença entre se arrogar o direito de mandar e governar quem manda. O império da mulher é um império de doçura, de habilidade e de complacência; suas ordens são carinhos, suas ameaças 
são lágrimas. Ela deve reinar na casa como um ministro de Estado, fazendo com que comandem o que quer fazer. Neste sentido os lares mais felizes são em geral aqueles em que a mulher tem mais autoridade: mas quando ela despreza a voz do chefe, quando quer usurpar os direitos dele e mandar sozinha, o que resulta da desordem é miséria, é escândalo, é desonra. (Rousseau, 1979, p.354).

Desonra, para quem?, poderíamos retoricamente nos perguntar. Mas é claro que é por isso mesmo que Rousseau caracteriza a mulher como politicamente subversiva, e clama urgentemente pela necessidade de seu impedimento. A portuguesa Fernanda Henriques é assertiva quanto à imputação à Rousseau a respeito das consequências deste discurso masculino público - douto e letrado, como também diria Kant em $O$ que é o Esclarecimento - sobre a vida política das mulheres: "De fato, pode-se considerar Rousseau um dos responsáveis mais determinantes pelas dificuldades que as mulheres tiveram - e ainda têm - para chegar a ser reconhecidas como uma individualidade com entidade ontológica capaz de protagonizar um modo de ser humano autônomo e livre e, consequentemente, capaz de assumir a cidadania na plenitude das suas dimensões" (Henriques, 2010, p.181). Cidadania que elas de fato não podem possuir, como Carole Pateman afirma e veremos subsequentemente, porque o conceito subjacente a essa 'individualidade' é a posse racional (pública) de si - coisa de impossível concepção para o pensamento rousseauniano, além de absolutamente desnecessária para as tarefas (privadas) a elas atribuídas.

Mas se os motivos são os da domesticação, e as justificativas publicizáveis aquelas da inaptidão para a cidadania, nada se compara aos planos bem desenhados do Malleus Maleficarum para a definitiva reputação do eco estridente sobre a materialidade mesma da nossa fala - replicada incontáveis vezes então pelos Modernos e Iluministas a troco de uma posse corporificada já mais ou menos assegurada pelo domínio exercido via políticas de extermínio em suas variadas facetas inquisitoriais, mecanicistas e colonialistas. É Silvia Federici quem chama a atenção para o fato de que "a caça às bruxas aprofundou a divisão entre mulheres e homens, inculcou nos homens o medo do poder das mulheres e destruiu um universo de práticas, crenças e sujeitos sociais cuja existência era incompatível com a dis- 
ciplina do trabalho capitalista, redefinindo assim os principais elementos da reprodução social" (Federici, 2017, p.294, grifo meu). Mas não apenas isso, senão que o processo assim instaurado destruiu violentamente o poder, o saber e os métodos das práticas contraceptivas e "institucionalizou o controle do Estado sobre o corpo feminino, o principal pré-requisito para sua subordinação à reprodução da força de trabalho" (Federici, 2017. p. 331). E, neste sentido, não é sem razão que a própria sexualidade da mulher seja demonizada nos termos de sua animalização. Na Questão VI do Malleus Maleficarum - Sobre as Bruxas que copulam com Demônios. Por que principalmente as Mulheres se entregam às Superstições Diabólicas - os inquisidores Kramer e Sprenger fornecem uma lista bastante instrutiva do "tipo de mulher que se entrega à superstição e à bruxaria" (Kramer e Sprenger, 1991, p.112) e que nos dá o tom de uma misoginia obstinadamente marcada sobre os nossos corpos e sobre os nossos atos cuja origem é sempre a corporeidade ela mesma: malícia, lascívia, cobiça, credulidade, impressionabilidade, fraqueza, malevolência e sedução, estupidez e imperfeição mental e moral, mentira, perversidade, temperamento irascível e colérico, vingança, inveja e ciúme, indisciplina, impulsividade, depravação, vaidade, e qualidades diabólicas que as tornam inimigas da humanidade. É doloroso. Mas é esclarecedor quanto às qualificações e hipóteses dos significados inerentes ao poder masculino e ao seu privilégio público e político.

Ora, os elementos deste retrato diabólico das mulheres se emaranham aos atributos a um só tempo animalizados, depravados e politicamente combativos. A sexualidade da mulher é carnal. É carne, na verdade. Nunca desejo, afeto ou vontade. Pura carne: "(...) O vocábulo mulher é usado para indicar a lascívia da carne" (Kramer e Sprenger, 1991, p.115), como sugerem os opróbios de certas obras cristãs. Ou ainda, de maneira definitiva: "Mas a razão natural está em que a mulher é mais carnal do que o homem, o que se evidencia pelas suas muitas abominações carnais" (idem, p.116). Essa carne é, inequivocamente, continuamente intercambiável com aquela dos animais não humanos, desde o estabelecimento dos limites de sua racionalidade às descrições de sua figura: "Um anel de ouro no 
focinho de um porco, tal é a mulher formosa e insensata" (idem, p.116, citação que, segundo os autores, advém dos Provérbios 11). E, de novo, conforme "Valério a Rufino": "Tu não sabes que a mulher é a Quimera, embora fosse bom que o soubesses; pois aquele monstro apresentava três formas: a cabeça, nobre e radiante, era a de um leão; o ventre obsceno era o de uma cabra; e a cauda virulenta era a de uma víbora" (idem, p.120). E se este disfarce é usado propositadamente para o ludibrio dos homens, o mesmo se passa, segundo os inquisidores, com uma outra propriedade saliente das mulheres - sua voz: "Mentirosas por natureza, o seu discurso a um só tempo nos aguilhoa e nos deleita. Pelo que sua voz é como o canto das Sereias, que com sua doce melodia seduzem os que se lhes aproximam e os matam. E os matam esvaziando as suas bolsas, consumindo as suas forças e fazendo-os renunciarem a Deus" (idem, p.120). Finalmente, para fechar o círculo da tumultuada corporeidade animalizada, tendo a bruxaria como um todo início na insaciabilidade sexual da mulher, o seu útero é considerado a "quarta boca" esfomeada da heresia (idem, p.121).

Diante disso tudo, é preciso que se contenha a "língua traiçoeira" das mulheres que "não se abstêm de contar às suas amigas tudo o que aprendem através das artes do mal" (idem, p.115), torná-las inimigas mútuas, controlar-lhes os atos, os discursos, o conhecimento, o corpo, a reprodução. Não à toa, o Malleus Maleficarum dedica um capítulo especial às parteiras que, de todas, são as piores bruxas, centralidade de um mal inerente.

Silvia Federici fala destes movimentos de terror sobre as mulheres como movimentos de reação, em um primeiro momento - a reação capitalista verdadeiramente reacionária, como aquilo que ela chama de "contrarrevolução" às lutas sociais anti-feudais, muitas delas lideradas por mulheres - e como movimentos de reação de medo, o medo do poder das mulheres. Claro, há muito poder na solidariedade feminina, na construção de um saber reprodutivo coletivo, que outorga a elas a autonomia sobre a reprodução, e sobre o próprio corpo, e que possibilita a vivência da sexualidade sem os freios da gravidez ou da vigilância pseudo-virtuosa sob as guardas da dupla moral. Essa vivência e esse saber constituem efeti- 
vamente um poder, permeado ainda pela confiabilidade e entendimento compartilhado entre mulheres. (Na verdade, era isso o que Rousseau queria dizer ao dizer que as mulheres são politicamente subversivas.) Os processos de caça às bruxas, sobretudo quando já institucionalizados e estatizados, minaram todas estas alianças e sua viabilidade de resistência. Coadunados com vasta literatura - dita científica, mecanicista, filosófica e religiosa - estes processos lograram uma segregação extremamente violenta entre homens e mulheres, solapando inclusive as potenciais identificações intra-classe, isolando as mulheres no ambiente doméstico e retirando de suas mãos ocupações já então desempenhadas, re-avaliando ao mesmo tempo o 'trabalho' e o 'salário' - ambos agora acepções masculinizadas, - e tornando-as pobres e dependentes da carreira do casamento, lugar onde impera o silêncio e a obediência. Assim, se a caça às bruxas foi o fenômeno que mais enérgica e eficientemente reduziu, ao criminalizar, o saber e a mobilidade pública das mulheres, foram também os processos supostamente pedagógicos - mas em absolutamente tudo políticos - levados a cabo pelos doutos e eruditos burgueses da Europa Moderna que contribuíram inestimavelmente para a criação de uma nova feminilidade, cuja função prioritária, senão unívoca, é a da maternidade e a do cuidado. Nas palavras de Rousseau, novamente:

Assim, toda a educação das mulheres deve ser relativa ao homem. Serem úteis, serem agradáveis a eles e honradas, educá-los jovens, cuidar deles grandes, aconselhá-los, consolá-los, tornar-lhes a vida mais agradável e doce; eis os deveres das mulheres em todos os tempos e o que lhes devemos ensinar já na sua infância. Enquanto não remontarmos a esse princípio, afastar-nos-emos do objetivo e todos os preceptores que lhes derem servirão de nada nem para sua felicidade nem para a nossa. (Rousseau, 1979, 312).

Ao fim e ao cabo, as metamorfoses ensejadas por Ovídio obtiveram êxito: as mulheres estão bovinamente domesticadas; sua voz soa doravante como um mugido vazio de significado; suas ações são uniformizadas para a produção de crias, leite e disponibilidade corporal. Que Zeus tenha transformado Io numa vaca para o seu contínuo benefício sexual como embuste ao ciúme de Hera, e que Hera a tenha requisitado para si porque, mesmo como vaca, Io ainda é o objeto do desejo pos- 
sessivo de Zeus, apenas reforça o modo como estas imagens intercambiáveis incidem estruturalmente sobre mulheres e animais não humanos a partir de um mesmo ponto hierárquico de poder. E esta é uma mitologia não menos repetidamente atualizável pelos padrões de consumo do mundo capitalista globalizado, cujas fêmeas humanas e não humanas seguem ao dispor de uma exploração emparelhada, ainda que tudo isso aflore, explicitamente, apenas na superfície da linguagem, restando escamoteado a maior parte do tempo (como o 'referente ausente' de uma política sexual da carne, conforme Carol Adams (2012)) - embora não, é claro, para a maior parte das fêmeas humanas e não humanas em seus corpos duplamente animalizados e femininizados. Momentos políticos, sociais e econômicos de ruptura ou de reacionarismo são propícios para a exteriorização das estruturas culturais que informam estruturas mentais hierárquicas.

No Dia Internacional da Mulher, em 08 de março de 2015, Dilma Rousseff foi xingada de "vaca" durante o seu pronunciamento em meio ao ruído de panelas e outros agravamentos. (Ela também foi chamada de "puta" e "arrombada" e eu voltarei a estes adjetivos abaixo). Ela já tinha sido assim chamada às vésperas dos debates eleitorais televisivos em outubro de 2014, e reiteradamente umas "600 mil vezes" - como afirmou em entrevista ao New York Times (Rousseff, 2017). Mas o significado desta atribuição de animalidade no dia em questão me parece incontestável relativamente aos desejos, senão aos efetivos processos, de reprivatização das mulheres quando sua voz é pública e, sobretudo, no universo público do que se costuma chamar de universo político. Como corrobora Mary Beard, "Cala a boca, sua vaca' é um refrão bastante comum" (Beard, 2018, p.46) e, muitas vezes, pelo único motivo de que a manifestação sonora de uma mulher se faz ouvir publicamente. Para nós, que elegemos democraticamente uma mulher para a presidência da República, os insultos não assentam como liberdade política de expressão e descontentamento, mas estão carregados de significados que reproduzem os edifícios patriarcais misóginos e que não ficam muito atrás do conteúdo didático dos manuais de caça às bruxas. Poderíamos pensar que, efetivamente, já não estamos 
lidando com fogueiras e enforcamentos mas tão somente com impedimentos governamentais, e que é um exagero da nossa parte retomar o discurso Moderno, ou o discurso inquisitorial, para comparações de rotulação contemporânea. No entanto, trata-se aqui do poder do discurso à outorga do próprio poder. "Essas palavras importam?", pergunta-se Mary Beard sobre o modo como "lamúrias" e "choramingos" soam, nas mulheres, quase como mugidos: "Claro que sim, porque sustentam um vocabulário que age para solapar a autoridade, a força e até o humor do que uma mulher tem a dizer. Trata-se de termos que de fato recolocam as mulheres de volta na esfera doméstica (as pessoas 'se queixam' de coisas como lavar a louça); trivializam suas palavras, as 'reprivatizam"' (Beard, 2018, p.40). E, note-se, finalmente, que os significados da 'domesticação' são duplamente inferiorizados porque duplamente atribuíveis à animalização $e$ à feminização do universo supostamente não político dos domínios privados da vida humana. $\mathrm{O}$ insulto funciona como insulto porque se logrou efetivamente assimilar a indignidade à animalidade e a pequenez e o servilismo às tarefas de reprodução da vida - sobretudo os degradantes e enfadonhos e infinitos afazeres domésticos, mas também aqueles de cuidado para com a vida animal não humana. Evidentemente, as possíveis associações mitológicas acerca da repetição e do sacrifício não nos levam aqui aos heroicos esforços de um Sísifo ou de um Atlas, mas àquelas que eternizam atividades, movimentos e comportamentos aplainados para toda uma classe de seres indistintos e assujeitados, sem sinais distinguíveis de subjetividade. Afinal, Io está condenada à passividade de sua disposição à manipulação alheia, em seu corpo, em sua voz e no esvaziamento do significado de suas expressões. Para acobertar os seus mugidos, ninguém mais precisa bater panelas - objetos estes igualmente sintomáticos da domesticidade - porque eles já nada significam e estão devidamente localizados nos currais ou nos quintais domésticos, longe dos ouvidos da praça pública e da publicização midiática. Assim, o xingamento funciona como xingamento, mas também como manifestação de um reiterado desejo político de cessão classificatória de capacidades e poderes - e posse exclusiva sobre o discurso. 
Seria este também o sentido do castigo e da maldição imposta sobre Eco? Não importa muito o fato de que tenha sido Hera a puni-la por suas conversas nas tentativas de Zeus de fugir ao seu adultério, porque já aqui está em curso o que o Malleus Maleficarum levará à perfeição relativamente ao caráter prolixo das mulheres e a maneira como este caráter está envolto ou resulta de ou em relações venenosas e vingativas e diabólicas entre criaturas do mesmo gênero. Eco não apenas falava demais, como parecia ter pleno domínio de suas ideias, além de se deixar usar tagarelamente por Zeus para fazer de Hera uma esposa irada - ainda que em prol de suas companheiras ninfas igualmente usadas por Zeus para outras coisas que não meras conversas. Daí a punição imaginada pela mitologia para a loquacidade feminina ser o completo esvaziamento de sua própria expressão. Falar somente como o eco do discurso dos outros, reproduzindo eternamente pensamentos que não são os seus.

As duas imagens de Eco - a entusiasta da fala e da palavra e aquela que está fadada a ser vista como mera reprodutora da oralidade alheia - são altamente significativas para os diferentes modos de descrédito efetuados sobre a fala das mulheres, sua autonomia discursiva e cognitiva, e sua capacidade argumentativa. Para começar, há esta pecha de tagarelas que nos persegue, junto de nossa aparente incontinência verbal. Quando os autores do Malleus Maleficarum qualificam as mulheres como "possuidoras de língua traiçoeira", como vimos acima, eles não apenas estão se referindo à traição à fé cristã realizada pelo mal presente nas ações e feitiços e fórmulas de bruxaria, mas à traição ao silêncio que acomoda a língua das mulheres em sua boca. Trata-se de uma caracterização impositiva sobre o fato mesmo da expressão, e não necessariamente sobre o seu conteúdo. É claro que a alegação da malevolência, mas também aquela da superficialidade e da vacuidade, serve de justificação para os retratos pintados pelos demonólogos e por outros literatos e dramaturgos preocupados com as possibilidades abertas pelo matraquear das comadres entre si na manutenção do seu poder comunitário e coletivo, cuja mútua solidariedade reforça uma independência feminina arriscada demais para o sistema patriarcal. Há que se domar as megeras. 
E para isso o caldo cultural, político e econômico do capitalismo nascente tem as suas manobras - conjuntamente orquestradas até mesmo pela contribuição dos próprios trabalhadores masculinos submetidos aos novos regimes de assalariamento - que dependem de uma construção discursiva eminentemente dicotômica e essencialista (e classista) e de uma aguda ruptura das relações cooperativas entre as mulheres. Em Mulheres e Caça às Bruxas, Silvia Federici explica o modo como a palavra 'gossip', cuja significação positiva estava relacionada à companhia, ao trabalho e à amizade feminina e a algum tipo de poder e independência social e econômica na era pré-Moderna, passa a designar pejorativamente a fofoca inútil e maledicente levada a cabo sobretudo por mulheres vaidosas, encrenqueiras e vingativas - com o sentido ainda hoje a elas atribuído. Os dois séculos posteriores ao Malleus Maleficarum - XVI e XVII - parecem ter sido decisivos para a "deterioração" do "papel social" das mulheres (Federici, 2019, p.79) e de sua sororidade, e não é à toa que o manual dos inquisidores construa e insista na "rivalidade deplorável" entre as mulheres que em seu ciúme e inveja "muito pior" ainda se comportam "com relação aos homens" (Kramer e Sprenger, 1991, p. 117), e que sua língua seja objeto privilegiado para detecção de bruxaria - ou, como diz Federici em outro lugar: "A língua feminina era especialmente culpável, considerada um instrumento de insubordinação" (Federici, 2017, p.202). Da chacota literária e do sermão religioso sobre indisciplina, loquacidade e impertinência à punição social é um passo, e as tagarelas são finalmente impedidas de falar ou ameaçadas de tortura, numa antecipação aos recintos de julgamento e condenação inquisitorial e numa espécie de reverberação mitológica do castigo infligido a Eco, com o uso de elaborados mecanismos de contenção da fala, como a "rédea da rabugenta" (scold's bridle ou gossip bridle), que literalmente "rasgaria a língua da mulher se ela tentasse falar" (Federici, 2019, p.81), ou como a "cadeira de imersão" (ducking stool) que é um nome bonito para uma cadeira, ou às vezes uma gaiola, que simula o afogamento - e que foi também usada para a punição das prostitutas quando a concepção institucional a respeito da prostituição passou por uma reforma rumo à criminalização, mais ou menos no mesmo período em questão. 
As impressões dos castigos impostos sobre as mulheres incapazes de conter sua língua, suas opiniões vazias e sua verborragia venenosa - elementos que compõem todo o quadro do mito de Eco, embora a vingança e o veneno provenham de Hera e não da ninfa - refletem ainda hoje sobre a imagem que as mulheres têm de si mesmas e sobre as representações políticas e sociais dos lugares que ocupam, ou que deveriam (naturalmente) ocupar, já que a princípio as conversas das comadres, as fofocas e as intrigas subversivas ficam às margens do público, nos ambientes destinados à domesticidade - pensemos no quanto nossas novelas replicam no lar esta informação. Neste sentido, contudo, o processo de privatização dos corpos femininos logrou não apenas este confinamento como também o seu isolamento e, desde que a nova feminilidade foi de fato instituída pelos moldes da família nuclear de modelo burguês-capitalista, as mulheres já não contam comunitariamente consigo mesmas, sendo não apenas mutuamente rivais como, agora, - na onda do empoderamento neoliberal - também economicamente concorrentes. Todo este longo processo e projeto político de desvalorização, rebaixamento e insulamento do feminino, diz Federici, deixou "marcas indeléveis em sua psique coletiva e em seu senso de possibilidades" (Federici, 2017, p.203). Afinal, que depois de tudo sejamos apenas capazes de repetir ideias alheias - que é a consequência dos atos autônomos de Eco como também a concepção fundamental da essência feminina determinada pelo silêncio forçado pelas rédeas ou pela ameaça de extermínio - é o que basta para explicar o nosso não-lugar no universo público da política, e que é um não-lugar mesmo quando por ventura algumas de nós conseguem chegar lá, já então esteticamente masculinizadas e politicamente reprovadas, como se mesmo aí ainda fossem incapazes de mais do que representar os seus próprios interesses mesquinhos (e privados): "São as mulheres que 'gossip', supostamente por não terem nada melhor a fazer e por terem menos acesso ao conhecimento real, à informação, e por uma inabilidade estrutural de construir discursos racionais, de base factual" (Federici, 2019, p.83). Daí a atualização do descrédito por meio daqueles fenômenos de sobreposição e monopólio da fala masculina mansplaining, manterrupting, bropriating... - que evidenciam o 
desconforto (o nosso e o deles) da ocupação do espaço público e político, fenômeno associado ao "caso da srta. Triggs", como o chama Mary Beard (2018, p.19) em referência à charge de Riana Duncan ("Excelente sugestão, srta Triggs. Talvez um dos homens aqui presentes queira executá-la"). E que evidenciam, claro, a continuidade da concepção sobre a racionalidade feminina como falha, imperfeita, não-argumentativa - não-racional, de fato. Eis que faz todo o sentido acabar como mera reprodutora da fala e do pensamento alheio, e que ao fim e ao cabo o castigo sobre a tagarelice de Eco tenha sido requalificado e modernizado, depois de devidamente assentados os recursos persecutórios de corporificação da feminilidade reprodutora, em rédeas psicológicas e bloqueios de manifestação pública.

Os bloqueios são igualmente sintomáticos dos desejos políticos masculinos de reprivatização das mulheres, porque a construção inacabada (interrompida, talvez fosse melhor dizer) de nossa autoestima (inclusive como classe) nos impede de fazer os devidos enfrentamentos à invariável campanha e política sexual de degradação de nossa imagem. A "sátira antimulheres", como chama Federici aos modelos literários tais como "O Parlamento das Mulheres" de 1646 e às miríades de gravuras e alusões pouco elogiosas do mesmo período a mulheres, sobretudo esposas, supostamente independentes, autônomas e superiores aos seus maridos (a preocupante e agressiva "dominatrix" de que fala David Underdown (1986)) continua sendo replicada nas capas das revistas e jornais contemporâneos à vivência política de Dilma Rousseff, Angela Merkel, Hillary Clinton, Theresa May, Michelle Bachelet. Todas elas muito parecidas entre si - independentemente das diferenças a respeito de seus programas políticos. Todas elas satirizadas por suas caras mais ou menos femininas, sobretudo quando suas expressões - infortunadamente materializadas em fotografias pouco elogiosas - e seus comportamentos parecem legitimar toda uma história de descontrole da língua, de prontidão à histeria, de incompatibilidade entre feminilidade e poder e política, e de inaptidão para o espaço público. O festejo do impedimento governamental de Dilma Rousseff com aquela saudação sarcástica e cáustica - "tchau querida" - apenas demonstra a impossibili- 
dade de qualquer estima pela figura feminina que ocupa um cargo de governo, decisão e autoridade, lugar especialmente visado, visível e vulnerável ao erro. Aqui, a falsa estima só é possível porque se dá na despedida, quando ela finalmente desocupa um espaço a ela confiado como por engano. Que as imagens dessa despedida sejam todas povoadas por homens brancos sorridentes nos dá a dimensão de que a história da tagarelice desequilibrada e colérica aparentemente legitimada pelos efeitos de uma política fadada ao fracasso (aquela de um Partido dos Trabalhadores comprometido demais com nichos das elites) é na verdade uma outra história: aquela do acesso masculino inquestionado ao poder e ao seu privilégio de circulação e posse exclusiva - do poder, do discurso, e dos corpos das mulheres, e de todos os outros corpos femininizados - ao mesmo tempo também infantilizados, racializados e animalizados.

Não se trata, portanto, do usufruto puro e simples do lugar do poder, mas do usufruto do lugar do poder como passagem e abertura à propriedade sexual.

Além da referência à denúncia do contrato sexual escamoteado pelo contrato social tal como realizada por Carole Pateman na esteira dos debates sobre a dicotomia entre o público e o privado, compreendo aqui a noção de 'propriedade sexual' como altamente abrangente, a ponto de incorporar características compartilháveis entre mulheres, homossexuais, transexuais, animais não humanos e o espectro explorável da terra (e da Terra). No entanto, neste momento, quero chamar a atenção para o modo como esta noção de propriedade conecta alguns dos aspectos mais violentos do ponto que tenho destacado ao longo desse ensaio e que se relaciona com a política da palavra e da linguagem e com a usurpação do poder de fala das mulheres, e que passa pela mitologia dos castigos imaginados como resposta à condição feminina, sobretudo em suas pretensões de liberdade sexual, cognitiva, sonora e política.

De alguma forma, as punições exercidas sobre Io e sobre Eco possuem o mesmo pano de fundo de uma política sexual destinada ao silenciamento e a uma vivência doravante inexprimível, que é o que as conecta também ao destino de Filomela, cuja língua é cortada por Tereu, seu cunhado, para 
que ela não possa denunciar o seu estupro. (Ela consegue depois bordar a denúncia e fugir com a irmã, ambas em forma de pássaros - porque nós podemos bem imaginar o que significaria ficar à mercê do estuprador denunciado numa ambiência patriarcal). Aqui, o seu corpo feminino está à disposição de uma dupla violência, mas que é em todos os sentidos orientada por uma mesma noção de propriedade sexual.

Ora, se a língua é instrumento de subversão política, e a liberdade corporal sexual é uma liberdade política, não apenas há que se domar as megeras, mas arrancar-lhes o poder de imputação e queixa, responsabilizando-as, inclusive, pelo próprio castigo. E não importa muito que a responsabilização recaia sobre os traços mais apreciáveis da feminilidade tal como socialmente construída e insuflada - como é o caso da Filomela shakespeariana Lavínia, em Tito Andrônico - ou que ela soe como ameaça por se ousar, em qualquer circunstância mas sobretudo no universo público da política, falar como um homem. Era dessa índole a ameaça e a responsabilização do estupro simbólico perpetrado pelos adesivos representando Dilma Rousseff de pernas abertas. Não se tratava de forma alguma, conforme alegação, de protesto político, mas da reprodução de uma política incansável de punição e usurpação de poder pela ousadia da liberdade política como subversão da estrutura masculina. No imaginário social, político, estatal e econômico, o estupro é corretivo de uma miríade de condições femininas: da lesbianidade, da ingenuidade, da virtude frígida, da mútua solidariedade feminina, da feiura, do próprio desejo sexual, e de incorreções governamentais. Note-se que a adjetivação mencionada anteriormente - "puta" e "arrombada" - salienta a disponibilidade corpórea como a punição mais adequada aos desvios que, de todo modo, são de sua inteira responsabilidade, o que inclui ainda, evidentemente, essa disponibilidade ela mesma. O Brasil contemporâneo tem sido pródigo em exemplificações deste imaginário pela boca mesma do atual governo e a impetuosidade da misoginia tem demonstrado paralelos com os momentos cruciais de reação às lutas sociais condicionantes à acumulação "primitiva" de capital, a qual, segundo Federici, na verdade não cessa de se reinaugurar. Neste sentido, - e tal 
como ela aponta relativamente à descriminalização do estupro e à legalização da prostituição no período da Alta Idade Média (Federici, 2017, p.103-104) - a banalização do estupro é também um expediente ideológico de controle e quebra da solidariedade de classe.

De todo modo, no entanto, o estupro não pode de fato constituir um problema para a sociedade quando as concepções dicotômicas e hierárquicas de gênero são baseadas na posse masculina da propriedade sexual feminina.

Acho que isso é determinante para a questão do motivo que já tinha sido levantada por Christine de Pizan relativamente à maledicência dos autores homens sobre as mulheres. E para o modo como suas ações subsequentes engendram a misoginia. (A ponto de a autora precisar fazer a defesa de que mulher alguma deseja ser violentada ou de que sente prazer numa "coisa tão abominável", mas "sim, uma dor inigualável", com o suicídio de Lucrécia servindo como seu primeiro exemplo argumentativo contra a desonra e a imoralidade do estupro (Pizan, 2006, p.266)). O que os motiva? Ora, o que os motiva é a conservação do livre acesso à corporeidade feminina.

N'O Contrato Sexual, Carole Pateman procede à história não contada do contratualismo como teoria política a serviço do patriarcado moderno - este supostamente situado contra o patriarcalismo clássico estruturado "no parentesco e no governo do pai". No lugar dessa ordem parcial e suspeitamente enviesada de "vínculos particulares", o mundo moderno estabelece o contrato como regulamento imparcial universal de legitimação e justificação do direito político, no qual "o 'parentesco' foi transformado na 'família', a qual tem seu princípio de associação e sua localização próprios na esfera privada, separada da sociedade 'civil' pública" (Pateman, 1993, p.52). O que já nos dá um vislumbre das determinações subjacentes a cada um dos atores envolvidos nesta trama. Ora, o cerne do contratualismo está na consolidação de uma sociedade civil cuja garantia de liberdade e de uma vida livre de violência é dependente da mútua confiança entre os seus signatários como indivíduos racionais livres e iguais sob uma e mesma proteção do Estado. O problema é que as mulheres não figuram nesta história como 
legítimas contratantes senão do contrato de casamento, já no âmbito privado da vida civil. Outro problema é que o contrato social dissimula tudo o que está em jogo na criação da esfera privada e no significado do 'privado' como salvaguardado das interferências do domínio 'público'. E tudo isso tem a ver com outro problema ainda, que é o fato de que as mulheres não são indivíduos tal como o conceito de 'indivíduo' é desenvolvido pelos contratualistas: como "proprietários". Daí elas não poderem assinar o contrato social. Porque a conquista da cidadania requer o estatuto da "propriedade que os indivíduos detêm em suas pessoas" (Pateman, 1993, p.20). E, para esta tradição, as mulheres "não têm os atributos e as capacidades dos "indivíduos" as quais lhes pudessem permitir a posse de si mesmas (idem, p.21). Essa é, portanto, uma característica da humanidade que as mulheres alienam aos homens devido à sua diferença sexual. Em última instância, é a diferença sexual que estabelece, no contratualismo, o contrato social explícito assinado pelos indivíduos detentores da propriedade em suas pessoas cujo objeto deveria ser a liberdade da sociedade civil em seu conjunto, $e$ o contrato sexual, assinado fraternalmente pelos mesmos indivíduos cujo objeto, agora, no entanto, são as mulheres ou "o acesso sexual aos corpos das mulheres" (idem, p.151). Afinal, se elas não são contratantes e não participam do pacto pela liberdade, ao mesmo tempo em que não são indivíduos, elas também não podem participar da esfera público-política da vida, e nem podem ser livres.

A dicotomia público versus privado é aquela que rege, consequentemente, a divisão sexual do trabalho, os domínios e o alcance da domesticidade e da natureza não-política das relações privadas e, finalmente, a natureza não-política das relações sexuais privadas, com a reprodução incessante das mútuas associações conceituais que colocam as mulheres de par com sua menorização meio-humana, meio-animal. Afinal, elas precisam de alguma humanidade para que os desejos heterossexuais masculinos tenham significado, ou como diz Pateman:

As mulheres não têm um papel no contrato original, mas elas não são deixadas para trás no estado natural - isso invalidaria o propósito do contrato sexual! As mulheres são incorporadas a uma esfera que ao mesmo tempo faz e não faz parte da sociedade civil, mas 
que está separada da esfera 'civil'. A antinomia privado/público é uma outra expressão das divisões natural/civil e mulheres/homens. (Pateman, 1993, p.29).

A denúncia de Pateman sobre a história não contada do contrato social, que problematiza a compreensão do contrato de casamento como um contrato entre iguais, é correlata à outra das histórias não contadas sobre a construção da feminilidade como inerente ao projeto capitalista, da caça às bruxas à exploração da maternidade para um novo conceito de 'família', tal como relatada por Federici. Para ambos os casos, importa perceber os efeitos da ficção de a-politicidade do espaço privado e doméstico e os significados atribuídos aos corpos em cada uma das esferas. Que a adesão ao contrato bem como ao projeto capitalista se dê também por aqueles sujeitos masculinos cuja alienação é da ordem do trabalho produtivo, apenas atesta a força da fraternidade do contrato sexual e do seu lugar de poder - que pode ser às vezes o único lugar de poder disponível na estrutura salarial hierárquica racializada do sistema econômico-político capitalista: "Se os homens são os chefes de família, eles têm o acesso sexual aos corpos das mulheres, mas esse acesso não pode ser fruto de um acordo mútuo porque os corpos das mulheres e dos homens não têm o mesmo significado político" (Pateman, 1993, p.151). E isso implica, evidentemente, que eles devem ocupar diferentemente cada uma das esferas, e que a subversão acontece, como bem o temia Rousseau, quando a denúncia das histórias não contadas escancara o aspecto político da pessoalidade, da privacidade, da domesticidade, e da continuada violência que passa como briga de marido e mulher ou como reafirmação da natureza dos sexos. Numa extraordinária passagem de Pateman, as essencializações legitimadas pela tradição política contratualista reafirmam e ecoam, sob a ficção Iluminista do acordo racional e do livre consentimento, aquelas composições da figura feminina tais como idealizadas pelos demonólogos d'O Martelo das Feiticeiras e seus juízes nos tribunais inquisitoriais, dando razão à Federici de que "foi precisamente nas câmaras de tortura e nas fogueiras onde se forjaram os ideais burgueses de feminilidade e domesticidade" (Federici, 2017, p.334), agora já consolidados por mulheres passivas como Sophie, e caladas como ninfas: 
As mulheres, seus corpos e suas paixões carnais, representam a "natureza" que tem que ser controlada e superada para que a ordem social seja criada e mantida. No estado de natureza, a ordem social na família é mantida somente se o marido for o senhor. O desejo feminino insaciável tem que ser controlado pelo direito patriarcal. As relações das mulheres com o mundo social têm que ser sempre mediadas pela razão do homem; os corpos das mulheres têm que ser sempre submetidos à razão e às decisões do homem para que a ordem não seja ameaçada. (...) A 'base natural' do direito masculino é a impossibilidade de as mulheres desenvolverem moralidade política necessária aos participantes da sociedade civil. (Pateman, 1993, 151).

Domar as megeras, arrancar-lhes a língua e torná-las estúpidas. Com o que elas apenas confirmam a afirmação de sua inaptidão para a fala e para o mundo público, sobretudo o mundo público da política. Neste sentido, a concepção subjacente ao modelo político contratualista do indivíduo como detentor da propriedade de sua pessoa é uma concepção que serve à posse masculina da propriedade sexual feminina na intrínseca relação entre patriarcado e capitalismo, amalgamando benefícios desta posição de posse do poder sobre criaturas que não são, de fato, pessoas e que podem, portanto, constituir objetos naturais de contrato. Benefícios que têm a ver também, evidentemente, com a continuidade e a garantia da paternidade sobre a prole - que interessa ao capitalista proprietário e herdeiro tanto quanto ao trabalhador assalariado para o aumento de sua capacidade de trabalho alienável. Pateman está falando do contrato sexual escamoteado pelo contrato social como um contrato de direito de livre acesso sexual às mulheres, e daí sua análise para outras questões para além do direito sexual conjugal, tais como a prostituição, a pornografia e a barriga de aluguel, todas elas passando pela ideia do significado político do corpo das mulheres como objeto disponível para sexo e do significado político do corpo dos homens como o corpo universalmente político por excelência. Mas ela está falando também do contrato sexual como implícito a uma ampla gama de aspectos e relações no mundo capitalista: "o direito de um único sexo" (idem, p.330) - a questão da construção de uma efetiva ideologia de gênero, novamente; embora Pateman prefira salientar o aspecto do sexo, e não do gênero, já as dicotomias em 
curso são dicotomias sexuais. Ora, é por isso - e esta é minha tese aqui, à qual eu retorno abaixo - que a posse da propriedade sexual feminina como posse sobre o corpo feminino é também uma posse sobre os desdobramentos de sua corporeidade (sua voz, sua fala, seu discurso, sua palavra, sua linguagem), instituindo com isso não apenas uma política sexual, mas uma política sexual do texto, da palavra, da linguagem - embora, em última instância, como fica patente pelos castigos mitológicos e pelas reiteradas desqualificações dos atos políticos das mulheres na política - a propriedade sobre a fala e sobre o poder se mostra e se expressa sempre novamente como propriedade de livre acesso sexual. Poderíamos quase dizer que a usurpação do poder de fala e do poder político instaura um direito de abuso e de exposição pública da sexualidade feminina como, publicamente, desfrutável. Daí o ridículo vir a compor os processos de destruição de uma imagem - ou da reputação e da honra que, como diz Pizan, também estão a serviço dos valores masculinos instituídos para a feminilidade: "Assim, em todas as questões, os homens querem ter razão e garantir os dois lados da moeda" (Pizan, 2006, p.271).

Apesar das aparentes mudanças de ordem legislativa, jurídica e estatal em vários Estados liberais capitalistas da atualidade em direção à inclusão e "empoderamento" das mulheres no "mundo civil masculino", Pateman afirma que nós ainda estamos sob os mesmos auspícios culturais e conceituais da tradição política contratualista, e que a necessidade da denúncia persiste em sua validade - "A ficção política ainda mostra sinais de vida", diz ela, "e a teoria política não é suficiente para abalar os seus sustentáculos vitais" (Pateman, 1993, p.342). Tanto mais, eu diria, diante dos retrocessos circundantes da política brasileira (e mundial, infelizmente), cujo espaço ocupado é sintomaticamente patriarcalista - e aqui, a 'família' governamental ganha ares de 'parentesco' novamente. Tanto mais ainda, que as manifestações misóginas parecem adquirir um novo fôlego com a legitimidade da autoridade instituída na presidência. O que os motiva? Ou por que nos odeiam? Se levarmos em conta as histórias não contadas da construção do espaço político e do espaço do discurso como espaço masculino, talvez o ódio não seja o motivo. Talvez 
o ódio seja posterior, chamado pela rebeldia das mulheres e sua insubmissão em tornar-se objeto possuído.

Uma insubmissão de longa data, evidentemente.

Se a teoria política cujo pano de fundo conceitual compartilha deste arcabouço contratualista fundado sobre a distinção público-privado, sempre ainda a serviço de uma estrutura capitalista, é insuficiente para uma subversão feminista da vida social, política e econômica, um novo expediente teórico deve ser buscado. Aparentemente, o presente ensaio não faz mais do que apresentar os aspectos mais conspiratórios - desumanizadores e desencorajadores - de um longevo projeto político de poder. No entanto, trata-se de um caminho de compreensão imprescindível para as subsequentes ações de desenlace dos nós patriarcais. Ou, como afirma Pateman: "Quando a silenciada história das origens políticas for trazida à superfície do cenário político, este nunca mais será o mesmo" (Pateman, 1993, p.341). Para a autora, trata-se de contar uma outra história conceitual sobre democracia, socialismo e liberdade. Mas para que possamos de fato chegar aí, precisamos igualmente pensar sobre aquilo que Mary Beard parece caracterizar como uma nova retórica do poder, cujo entendimento, para ela, remonta a muito mais longe do que a Modernidade: "O que precisamos é de alguma antiquada e séria conscientização a respeito do que queremos dizer com 'voz de autoridade' e de como viemos a construí-la" (Beard, 2018, p.53). Tais movimentos de reflexão, eu gostaria de propor, fazem parte daquilo que estou chamando de política do texto, da escrita e da linguagem, em oposição à política hierárquica e excludente de antemão golpista e de antemão inscrita no que conta como texto, como escrita e como linguagem, num processo de questionamento da legitimação do discurso masculino como discurso. Dito de outro modo, trata-se de pensar os significados do poder do discurso - na fala, no texto, na palavra - e sobretudo do discurso filosófico desenvolvido como discurso filosófico e como teoria política, cujas possibilidades comportam engajamentos subversivos e insurreições democráticas. Para deixar claros estes últimos objetivos, talvez devêssemos nomeá-la - de par com outros movimentos 
de reflexão de revisão conceitual e histórica - como uma política feminista do texto, da escrita e da linguagem.

As autoras presentes neste ensaio me parecem participar desta noção, não só pela busca ampliada da compreensão do estado de coisas histórico e conceitual excludente das mulheres e dos outros seres femininizados, como pelo engajamento metodológico ele mesmo subversivo das ordenações argumentativas do universo filosófico. É neste sentido que uma história feminista da filosofia corrobora com esta política do texto, ao recuperar as vozes, os textos e a escrita de mulheres deixadas retoricamente à margem por questões de poder - e não por questões de texto. Se este é de fato o poder e se os seus significados podem ser subvertidos em direção a um horizonte democrático inclusivo, uma política feminista do texto, da escrita e da linguagem é potencialmente transformadora do que significa o poder ou a "voz da autoridade" e a possibilidade da liberdade da palavra como uma liberdade política.

Desde aí, creio, será possível construir um novo expediente teórico que supere as amarras dualistas da filosofia política para, como também deseja Pateman, "uma nova história da liberdade" - que não poderá prescindir em algum sentido possível, do conceito de 'coletividade' contra o conceito empreendedor e proprietário de 'indivíduo' (livre). Por isso, este expediente teórico evoca um significado caleidoscópico de projeto ético e político (ecofeminista e complexo (Sattler, 2019)) em vista dos diferentes prismas e paisagens conceituais interdependentes abertos pela resistência ao sentido unívoco das histórias filosóficas e políticas aqui comunicadas. A franca e destemida abertura à porosidade dos significados (políticos) do texto, da escrita e da linguagem é ela mesma subversiva em sua natureza persistentemente inacabada. 


\section{Referências:}

Adams, Carol J. A política sexual da carne. A relação entre o carnivorismo e a dominância masculina. Tradução de Cristina Cupertino. 1 ed. São Paulo: Alaúde Editorial, 2012.

Beard, Mary. Mulheres e poder. Um manifesto. Tradução de Celina Portocarrero. São Paulo: Planeta do Brasil, 2018.

Federici, Silvia. Calibã e a bruxa. Mulheres, corpo e acumulação primitiva. Tradução Coletivo Sycorax. São Paulo: Elefante, 2017.

Federici, Silvia. Mulheres e caça às bruxas. Tradução de Heci Regina Candiani. São Paulo: Boitempo, 2019.

Henriques, Fernanda. 'Rousseau e a exclusão das mulheres de uma cidadania efetiva'. In : O que os filósofos pensam sobre as mulheres. Maria Luísa Ribeiro Ferreira (org.). São Leopoldo: Editora Unisinos, 2010, p.181-201.

James, Henry. Henry James on Culture: Collected Essays on Politics and the American Social Scene. Pierre A. Walker (ed.), University of Nebraska Press, 2004.

James, Henry. The Bostonians. (From a 1921 edition). The Floating Press, 2009.

Kramer, Heinrich e Sprenger, James. O Martelo das Feiticeiras. Malleus Maleficarum. Tradução de Paulo Fróes. Introdução de Rose Marie Muraro. 6ª ed. Rio de Janeiro: Rosa dos Tempos, 1991.

Pateman, Carole. O contrato sexual. Tradução de Marta Avancini. Rio de Janeiro: Paz e Terra, 1993.

Pizan, Christine de. 'A Cidade das Damas'. In_: Calado, Luciana Eleonora de Freitas. A Cidade das Damas: a cōnstrução da memória feminina no imaginário utópico de Christine de Pizan. Estudo e Tradução. [Tese de Doutorado]. Recife: UFPE, PPG Letras, 2006.

Rousseau, Jean-Jacques. Emílio ou da educação. Tradução de Sérgio Milliet. 3 ed. DIFEL, 1979.

Rousseff, Dilma. 'An Impeached President, Reeling but Defiant'. By Ernesto Londoño. April 13, 2017: https://www.nytimes. com/2017/04/13/opinion/an-impeached-president-reeling-but-defiant.html. Data do último acesso: 10 de janeiro de 2020.

Sattler, Janyne. 'Insurreições feministas da modernidade: A utopia de Margaret Cavendish'. In : Ensaios filosóficos de feministas brasileiras. Damião, Carla; Colan̄toni, Ana Gabriela (org.), Goiânia, UFG, 2020. (No prelo).

Sattler, Janyne. 'Presidenta'. In : O futuro da democracia. Hartung, Miriam (org.). Florianópolis, UFFSC, 2020a. (No prelo). 
Sattler, Janyne. 'Presidenta'. Relatos Circunstanciais do Ser Feminino. Ensaios literários. Blog: https://relatoscircunstanciais.blogspot. com/. Data do último acesso: 10 de janeiro de 2020.

Sattler, Janyne. 'Uma questão de forma: lições metodológicas com Martha, Cora e Christine'. In_: Vozes Femininas na Filosofia. Ana Rieger Schmidt, Gisele Dalva Secco e Inara Zanuzzi (org.). Porto Alegre: Editora da UFRGS, 2018, p.143-170.

Sattler, Janyne. 'Um projeto ecofeminista para a complexidade da vida'. In : Ecofeminismos: fundamentos teóricos e práxis interseccionais. Daniela Rosando, Fabio A.G. Oliveira, Príscila Carvalho e Tânia Kuhnen (org.). Rio de Janeiro: Ape'Ku, 2019, p.167-190.

Underdown, David. 'The Taming of the Scold: The Enforcement of Patriarchal Authority in Early Modern England'. In_: Fletcher, Anthony; Stenvenson, John (eds.). Order and Disorder in Early Modern England. Cambridge: Cambridge University Press, 1986, p.116-136. 